\title{
"They're Going to Tear the Doors Off This Place": Upper-Middle-Class Parent School Involvement and the Educational Opportunities of Other People's Children
}

\author{
DANIEL J. McGRATH and PETER J. KURILOFF
}

\begin{abstract}
This study explores social class and racial differences in parents' school involvement. Furthermore, it examines involved parents' intentions concerning school. Data are from a yearlong observation of parent-educator relations at a suburban school district in the northeastern United States. Highly involved parents tended to be White, upper-middle-class mothers. This happened, in part, because involved mothers frequently acted in ways that excluded other mothers, particularly African Americans. Involved mothers pressed administrators for additional tracking. This was a strategy for separating their children from lower status children and positioning their children for higher education. We discuss implications for school policy.
\end{abstract}

THE CURRENT emphasis among educational policy makers and researchers on raising levels of parent school involvement and increasing schools'

AUTHORS' NOTE: This research is supported in part by the Center for Developmental Science (NICHD T32-07376). The ideas expressed are those of the authors and do not reflect those of the Center. The authors would like to acknowledge a number of people who contributed to the study at various points, including Wendy Hobbins; Peshe Kuriloff; Peter, Barbara, and Maurice McGrath; Sheldon Goldberg; Bruce Kowalski; Emery Leonard; Steve Hocker; Allison Gonyeau; Mark Stern; and Elizabeth Useem, as well as two anonymous reviewers. Finally, we would like to thank the parents and educators of Minsi Trail for their patience and insight. Address correspondence to Daniel J. McGrath, Education Statistics Services Institute, American Institutes for Research, 1000 Thomas Jefferson Street, NW, Suite 400, Washington, DC 20007; e-mail: dmcgrath@air.org.

EDUCATIONAL POLICY, Vol. 13 No. 5, November 1999 603-629

๑) 1999 Corwin Press, Inc. 
accountability to parents largely has failed to account for the real dangers some kinds of parent involvement pose to children's equal opportunities for educational resources. Advocates of expanding parent school involvement typically envision extending a voice and improving services to those traditionally underserved by schools. However, two aspects of parent involvement in the late 1990s suggest that increased emphasis on parent involvement and schools' accountability to parents actually may subvert such egalitarian aims. First, parents differ by social class, race, and ethnicity in their access to schools and in their effectiveness in dealing with educators. Second, the concerns of involved parents often are narrow and aimed primarily at gaining advantage for their own children. Thus, rather than improving educational opportunities for all families, inviting parental involvement unthoughtfully may further focus school administrators' attention on those families that already have disproportionately high access to schools.

This article is an effort to deepen our understanding of social class- and race-based differences in levels of parent school involvement. In so doing, it cautions policy makers and school administrators about the unintended consequences of traditional efforts to increase parental involvement. We show how such efforts can further advantage wealthier parents while actually creating impediments to involvement among working-class and minority parents. We first locate our research within the context of the parental involvement literature. Then, using field notes from a yearlong participant-observation study of parent involvement in a suburban school district in the northeastern United States, we describe, first, social class and racial differences in parent school involvement and, second, involved parents' motivations concerning the distribution of children in programs and tracks. ${ }^{1}$

\section{ENTHUSIASM AND CONCERNS ABOUT PARENT INVOLVEMENT}

Expanding parent involvement in schools-parents as volunteers and as decision makers - has become a regular theme in policy initiatives, requests for grant proposals, and school reform efforts in the United States (Epstein, 1991; Perry \& Tannenbaum, 1992; Philadelphia School District, 1995; Warner, 1991). For policy makers, parent involvement in schools represents a method for, first, improving schools' services to families by making schools more accountable to parents; second, strengthening ties between schools and families traditionally underserved by schools; and, third, better serving students by taking advantage of parents' rich stores of knowledge about their 
children (Comer, 1984; Levin \& Hopfenberg, 1987; Moles, 1987; Rich, 1988). Furthermore, the emphasis on parent involvement reflects policy makers' and educators' recognition that parents are key stakeholders in their children's education (Warner, 1991).

Increasingly, however, researchers are raising concerns about the impact of parent involvement on equal educational opportunity for students. In fact, some have suggested that parent school involvement is a mechanism through which socioeconomic advantage is reproduced across generations (Lareau, 1989; Lareau \& Shumar, 1996; Wells \& Serna, 1996). Research concerning families and schools has found that schools tend to serve parents differently by race and social class-just as schools have long served students differently by their race and social class (Connell, Ashenden, Kessler, \& Dowsett, 1982; Fair Access, 1996; Saravia-Shore \& Martinez, 1992). Moreover, parents, generally, enter school decision-making forums at information and power disadvantages compared with educators (Fine, 1993). But information and power relationships differ considerably with the social class and racial background of the parents. Upper-middle-class parents, especially White upper-middle-class parents, tend to have more success making their voices heard in schools because they have political power and because they carry an implicit threat of flight from public schools (Kohn, 1998). Conversely, inner-city parents, who often are the focus of parent involvement plans, are particularly likely to be at a disadvantage in their dealings with educators. They can find themselves being used as pawns in the battles of larger political forces-for example, between school administrators and teachers' unions (Fine, 1993).

Researchers have raised concerns related to differences in the educational resources parents of varying wealth and social status can provide their children (Baker \& Stevenson, 1986; Lareau, 1989; Lareau \& Shumar, 1996; Useem, 1992). In particular, upper-middle-class parents, acting principally through mothers, tend to be more involved than others in the management of their children's school careers (Baker \& Stevenson, 1986; Useem, 1992). This involvement makes more salient social class and racial differences in parents' own educational attainment and in their knowledge of the workings of schools. Mothers of higher social strata are more likely to select college preparatory classes for their children and have their children placed in higher academic tracks (Baker \& Stevenson, 1986; Useem, 1992). These parents are more likely than less educated and working-class parents to understand the ramifications of placements in college preparatory tracks for their children's later educational and economic opportunities. Even among children with similar course grades, the children of more highly educated mothers are 
more likely to be placed in college preparatory courses (Baker \& Stevenson, 1986).

Another set of concerns involves the role schools play in parents' lives. Researchers have found substantial differences in the approaches uppermiddle-class and other parents take toward schools (Lareau, 1989; Useem, 1992). ${ }^{2}$ For example, professional-class parents and working-class parents tend to form very different social networks. Professional-class parents are more likely to network through school relations-educators and other parents in the school; working-class parents are more likely to network within families and neighborhoods (Lareau, 1989). The social networks that upper-middle-class parents form through schools help them to gain crucial knowledge about the workings of schools and to make influential social contacts.

Finally, researchers are becoming concerned with the intentions of upper-middle-class parents (Kohn, 1998; Wells \& Serna, 1996). Uppermiddle-class parents are seen as resisting progressive school reforms that may extend opportunities to other families' children, expose their own children to those of lower social status, or redistribute educational resources more equitably. We do not know, however, the extent to which highly involved upper-middle-class parents share this resistance to progressive reform. Involved parents may share educators' interests in school reform. On the other hand, they may approach schools with the same narrow interests of many other upper-middle-class parents. If so, their access to schools may pose a considerable challenge to progressive efforts to reform schools.

In this study, we explore more deeply upper-middle-class parents' school involvement. First, we examine influences on the levels of school involvement among parents of differing social class and racial backgrounds. The focus here is on the impact of upper-middle-class White parents' school involvement on the involvement levels of other parents. We find that the social class differences in parents' networking found by Lareau (1989; Lareau \& Shumar, 1996) can be understood within the context of upper-middle-class White parents' ongoing access to schools. Second, the article examines involved parents' interests in the tracking and sorting of children. We discover, as Kohn (1998) and Wells and Serna (1996) suggest, that elite parents' advocacy for tracking is often driven by their desires to separate their children from those of lesser social status and to gain for their children access to the highest proportion of educational resources possibleoften at the expense of other parents' children (though we make no claim that upper-middle-class parents consciously recognize these distributive consequences). 


\section{PARTICIPANT OBSERVATION AT A SUBURBAN SCHOOL DISTRICT}

To examine these issues, we conducted a participant-observation study of parent school involvement at a suburban school district outside a major northeastern U.S. city during the 1995-1996 school year. Minsi Trail Schools served three municipalities in the suburban ring outside the city. ${ }^{3}$ The catchment area population was approximately 32,000 (Bureau of the Census, 1996). The student population was $80 \%$ White, $12 \%$ Black, $6 \%$ Asian American, and about 2\% Latino (Minsi Trail School District, 1996).

None of the municipalities was poor, but wealth and race varied sufficiently among and within municipalities so that class and race were significant issues in the school district community. The school district served two wealthy suburban towns and a working-class borough. ${ }^{4}$ According to the 1990 U.S. Census, per capita incomes of Whites and Asian Americans were twice the per capita income of Blacks in Minsi Trail (Bureau of the Census, 1996). But this reflected the high incomes of Whites and Asian Americans, rather than low-income Blacks. In fact, the per capita incomes of each racial group in Minsi Trail was twice the group's national per capita average. There were few poor children in any of these municipalities.

Still, some White parents and educators described Black neighborhoods as desperately poor. In their minds, race apparently served as a marker of social class. Most African American families lived in the working-class borough or in a neighborhood called Run in one of the wealthier townships. White parents and educators spoke of Run, especially, as being downtrodden, but African American administrators described the neighborhood as solidly middle class.

Overall, most Minsi Trail children fared well academically. Nevertheless, African American students, especially African American males, were disproportionately assigned to special education programs (Minsi Trail School District, 1996). The school district reported racial breakdowns of school program placements in a manner that hid this fact, because, according to one administrator, district administrators feared a possible response from the local chapter of the National Association for the Advancement of Colored People (NAACP). This overrepresentation of African American children in special education programs fed the perception among upper-middle-class White parents that these were not children with whom their own children should "rub elbows."

These concerns of administrators and White parents occurred within a districtwide context in which administrators envisioned individual parents as customers (see McGrath \& Kuriloff, 1999). Thus, at public meetings, the 
superintendent called on parents to think of Minsi Trail as a private school and to compare the district with local private academies. He described his schools as similar to the local private schools in terms of test scores but better than those schools because of their racial and ethnic diversity. Thus, he extolled the fact that Minsi Trail offered predominantly White uppermiddle-class parents an opportunity to expose their children to other children from diverse backgrounds. In practice, however, the "parent-as-customer" atmosphere fostered by administrators limited the mixing of White and Black students in classrooms. Administrators allowed parents to re-place their children in ability tracks, on grade-level teams, and in classrooms. Uppermiddle-class White parents were most likely to take advantage of these opportunities (McGrath \& Kuriloff, 1999). And, as we shall see, these parents were often motivated by desires to separate their children from African American students.

Observations and interviews with parents, teachers, and administrators were intended to describe parent-educator relations, investigate the influence of parent involvement on the distribution of educational resources, and explore structural factors underlying parent-educator relations. Following Metz (1988), we approached the schools through the daily routines of the educators and involved parents. We observed parent-educator interactions as they arose in the work lives of the educators and the school lives of the parents. Over the course of the 1995-1996 school year, the senior author observed 53 school days, divided among the district's six schools, spending each day with a teacher or an administrator. In addition, he observed parent-teacher meetings, administration meetings, districtwide meetings involving educators and parents, and public forums of interest to parents. Observations focused on the relationships between parents, teachers, and administrators.

The senior author interviewed all the observed educators ( 33 teachers and 22 administrators) and 30 sets of parents ( 24 mothers and 11 fathers). The parent interview sample included parents from each of the major social class and racial groups and included parents who varied in their levels of school involvement. The largest single group of interviewed parents comprised highly involved, White, upper-middle-class mothers. Interviews averaged an hour in length. Interview content was similar for educators and parents, including open-ended questions designed to learn about parents' and educators' family backgrounds, their careers, the school involvement of their own parents, their experiences with schools and with their children's schools, and their views on the proper roles of parents in schools and the proper functions of schools (see appendix for interview protocol). 


\section{SOCIAL CLASS, RACE, AND LEVELS OF MOTHER INVOLVEMENT IN SCHOOLS}

In Minsi Trail, levels of school involvement-including active home and school association membership, involvement on parent-educator committees, and attendance at public information and discussion forums-differed by gender, race, and social class. Nearly all of the parents involved in these activities were mothers. As interviews and observations revealed, most of these mothers were upper-middle class. Their husbands typically worked as professionals, often in the area's large high-tech firms or in major companies in the city. The mothers, themselves, often came from well-to-do families and had pursued professional careers. The vast majority of highly involved parents were White. Throughout the school year, African American parents accounted for an average of $3 \%$ of the parents attending these kinds of gatherings-although African Americans made up 12\% of the student population (Minsi Trail School District, 1996). Because these meetings were fairly small, an African American mother attending could expect to be one of one to three African Americans present.

Our fieldwork showed that factors influencing levels of school involvement turned out to be both structural and related to the interests and actions of parents. First, involvement in many school activities required a schedule flexibility that working-class mothers simply did not have. Second, schools appeared to have played a larger role in the lives of many upper-middle-class White mothers than it played in the lives of other mothers. Third, the highly involved mothers acted in ways that tended to exclude mothers from other social class and racial groups.

\section{Availability for School Involvement}

A major influence on differing levels of parent involvement was the mothers' availability for school activities. Much of the school volunteer work, including most parent-educator meetings, occurred during the school day. Involved mothers needed flexible schedules in order to attend these meetings. The highly involved mothers tended either not to work for pay, to work parttime, or to hold jobs that allowed them to be involved at school. Of five home and school association copresidents interviewed, two were not working for pay in 1995-1996, and the other three held jobs that allowed them the flexibility to make their own hours. ${ }^{6}$ This is not to say that the involved mothers had lots of free time. Two of the copresidents were nurses and another ran a family day care center out of her home. However, they all, in some way, were able to make their own hours. 
Being able to spend many hours with educators and other parents and being available at specific times affected parents' social networks and the information and influence they gained through them. The following illustrative passage is taken from an interview with Elsie and Ed Walker. Mr. Walker was a professional working at a large firm in the city. During the interview, the Walkers talked about Mrs. Walker's school involvement. They called it her "job." Mrs. Walker had worked in home and school associations and had picked teachers, academic tracks, and teams for her two children over the years. When asked how she learned about the workings of school-for example, who the good teachers were- she said $^{7}$

Talking to people at athletic events, home and school meetings ... stuffing newsletters. We did that up until this year. We have given that up, because it was too much time. But, I found those [envelope stuffing sessions] valuable, because you would sit around and talk. And that's when you find out the things you really want to know. (Parents, interview, January 28, 1996)

School involvement was a job in the sense also that it had financial implications for families. In communities as wealthy as the Minsi Trail municipalities, even upper-middle-class families felt the financial sacrifice of one parent staying at home. These parents were mainly women who could have pursued full-time professional careers. Indeed, many of them did pursue such careers, albeit with scaled-back hours. The involvement of these mothers in schools did not occur in an opportunity vacuum or without opportunity costs.

Although Mr. Walker made a substantial living, the Walkers felt that they had compromised economically for their children's sake by choosing to have Mrs. Walker volunteer at school rather than pursue a full-time career. The Walkers spoke explicitly about the trade-offs they had made.

Mr. Walker: "In a public school setting, there is something to a squeaky wheel getting the oil. So, if I were to give advice to a parent, [it would be to] get to know the teachers, children's friends, and classmates. Be active and be involved. And that's hard for working parents in particular. It's a special challenge. Not to [denigrate Mrs. Walker's involvement at school as a nonworking mother]."

Mrs. Walker: "Yeah, if I worked we'd have a double salary and we would have more things. But we've chosen that I not work and given up that income. Now a lot of people don't have that luxury, but a lot of people do. And there's a lot of people who don't work who don't get involved anyway. It's a question of your priorities. ... I don't believe in the super mom who can do it all." (Parents, interview, January 28, 1996)

If upper-middle-class parents felt the economic pain of mothers' school involvement, many working-class and single-parent families found school 
involvement a luxury they could not afford. Educators attempted to broaden parent involvement by holding school information sessions and decisionmaking meetings outside school hours. These efforts tended to draw middleclass and upper-middle-class mothers and fathers. But the evening meetings tended not to attract minority parents. African Americans, particularly, were absent from these sessions. Similarly, the general meetings of most home and school associations were held at night, which expanded the number of mothers and fathers involved but not the racial diversity.

Thus, the relative absence of African American parents from school involvement could not be explained fully by differences in availability during school hours. African American parents were as underrepresented at night meetings as at those held during the school day. Furthermore, although African Americans had lower average incomes in the school district as compared with their White peers, there were significant numbers of upper-middle-class African American families in the district (McGrath, 1997). Yet, these mothers were not nearly as active in schools as were the upper-middle-class White mothers.

\section{Incidental Exclusion}

Access to school involvement differed by race partly because the involved upper-middle class White mothers often behaved in ways that excluded other mothers, especially African American mothers. The home and school associations at Minsi Trail were run predominantly by upper-middle-class and middle-class White mothers. Administrators and the involved mothers themselves would sometimes call the home and school groups cliquish. However, these cliques were unintentional. Involved mothers said they wanted more parents to become involved. They often complained about the low numbers of active parents. But the way these mothers acted tended to exclude others, especially African American women.

This behavior is illustrated in the following passages from a Principals and Presidents Meeting in the autumn of 1996 and a home and school association meeting the same night at one of the wealthier elementary schools. ${ }^{8}$ The first passage is taken from near the close of the Principals and Presidents Meeting.

Assistant Superintendent: "What are some other concerns of yours?"

Carolyn Mitchell [a home and school co-president]: "Leadership training for parent volunteers? In terms of trying to bring up core groups to take over for us."

Michelle Wiley [home and school co-president at another school] takes issue with Carolyn's idea. Mrs. Wiley talks about being able to spot people who would be good in the home and school. She wants the home and school co-presidents to recruit 
members individually. "We're already too busy with doing things." At another point, she says, "I spot people by body language."

Mrs. Mitchell argues that they are losing good volunteers, because the parents do not know how to volunteer effectively, do not know how to be leaders in the school. She says, "Well it's not that certain personalities can be leaders, it's that certain skills are needed for leaders. And we could offer programs to draw these people out."

The Pine Grove Principal pitches in that she agrees with Mrs. Mitchell. The Assistant Superintendent agrees, as well.

Melanie Fonda, a co-president at another school, starts talking about cliques. She says the home and school associations are having difficulty welcoming new parents. Also, some parents are feeling used; they feel isolated into the little job they are doing for the home and school. "You have to keep those people," she says.

The Assistant Superintendent offers half day programs for training parents as volunteers.

Mrs. Wiley: "I really don't think you're going to draw the apathetic with another irritating meeting."

Other parents and the principals begin to nod in agreement with her.

The Assistant Superintendent says that no, "we're talking about everybody finding a person to mentor, just as you were talking about."

Mrs. Wiley disagrees. She says that "people just want something to do."

The Twin Brooks Principal disagrees: "Speaking only for Twin Brooks, we do not do enough to break up cliques." This statement is greeted with lots of nodding by the others.

[The issue is unresolved and the meeting ends]. (Field notes, October 18, 1995)

Mrs. Mitchell was trying to offer an opportunity to involve parents who were unlike these upper-middle-class White mothers by suggesting programs that could draw out different kinds of people. The sense during the meeting was that she was only talking about involving parents who lacked the leadership skills and possibly the initiative of the copresidents. However, it would be consistent with our conversations with her to expand her statement that it is "not that certain personalities can be leaders" to include that it is "not that only certain people can be leaders." In other words, she was asserting that, given the chance and training, people unlike the involved upper-middle-class White women could be effective leaders in the home and school associations. Through recruitment and training, the home and school associations could involve more parents and use them more effectively. But, in the excerpt above, Mrs. Wiley described how recruitment worked in practice in the home and school associations: Certain people (those with the right "body language") were welcomed into the home and school associations and others were not.

Parents may not have intended to exclude others. Most parents were too busy for another "irritating meeting." And, because involved parents were 
also busy, they were not conscious of the ways they excluded or silenced others. The following passage is from a home and school association meeting at an elementary school the same evening as the Principals and Presidents Meeting. There were 40 parents in attendance, including a single African American couple. Brenda Wilkes, the mother in charge of the membership drive, has just reported that the drive is not going well.

A mother named Sandra asks about withdrawing from the national organization. She wants all of the money to stay in the local home and school association. Alice Cooper, one of the local home and school co-presidents, says that it is a hassle to get out of the national organization, and that there is nothing really wrong with staying in it. Sandra: "Except they take two dollars and twenty-five cents." Mrs. Cooper responds that the district's other elementary schools' home and schools cost more. Sandra says, yes but their money goes to the school.

Ellen Forbes, a home and school officer, is standing in the back of the room. She is visibly exasperated. She says that the reason they originally joined the national organization was for the national lobbying, "and sometimes locally, it gives us a little extra leverage. So, you have to decide if you support the legislation." [She is saying that their home and school is accorded more respect at the district because they belong to the national. She is also suggesting that the national's lobbying efforts are worth supporting.]

The woman is now satisfied.

Another woman makes a motion to investigate whether they want to stay in the national. Silence. Then, another woman says that she is new, but she thought twice before joining, because so much money goes to the national.

There is much discussion in the background, women talking to each other about the proposal. The treasurer says to the group, "It's never been a problem before. If you don't want to support it don't, but can we move on?"

Someone says there is a motion and it needs to be addressed. Mrs. Forbes says we need a second and then two-thirds voting yes on the motion to pass it. Mrs. Cooper presents a motion to leave the national. No response. Then someone says, "That's not the motion." The woman who had made the original motion repeats her motion to investigate leaving the national. Then, Mrs. Forbes repeats the motion. A voice vote follows and it is unresolved. Then a vote by hands. The count is 14-17 in favor of the motion. Motion is defeated.

Another woman says that she has an idea for a fundraising table at a future event.

Marie Hatfield, a longstanding member, responds defensively: "I am the committee. If someone wants to volunteer to join the committee, I'll give 'em the stuff and they can get a table."

Mrs. Forbes goes back to the vote concerning leaving the national: "We don't keep track of who are members. We don't look for cards [at the meetings]. If you don't want to join the national, that doesn't mean you can't come here and have your voice heard."

Another committee report. 
Then, Jan Dando brings up this morning's Principals and Presidents Meeting. She says how it was raised at the meeting that there are cliques in the home and school associations. "Please, if you meet someone or know someone, ask them to join."

The lone African American woman at the meeting stands and says, "Thank you for saying that." She talks about being new to the school "and you all carry on your meetings as if you all know what you're talking about, and I don't know."

Mrs. Cooper responds, brightly, "Yes, we were all there six years ago." (Field notes, October 18, 1995)

Throughout the meeting, there was a clear distinction in attitude between the mothers who were involved in the home and school association-the "we" to whom Mrs. Forbes referred-and those who were new or not involved. Furthermore, although the copresident said she wanted to include more parents, much of what the involved mothers actually did tended to shut off new parents. At least one of the officers, for instance, was exasperated by the talk about leaving the national organization. Certainly, to longstanding members, the renewal of old arguments with new members must become tiresome-especially when the established members feel overworked. However, the topic generated a great deal of interest among the newer and less involved parents. Another example of the involved mothers' exclusive behavior was Mrs. Hatfield's defensiveness concerning her fund-raising methods. She was not interested in additional fund-raising events. She simply wanted additional fund-raisers. However, her manner was not at all inviting. These kinds of behaviors among the involved parents acted to exclude other parents from extensive home and school association involvement.

A final example from the passage links the unintentionally exclusive behavior of the involved White mothers explicitly to race. When the only African American mother in the meeting expressed her difficulty in fitting into the group, the home and school association copresident told her, "Yes, we were all there six years ago." Clearly, the White copresident did not show appreciation for the risk taken by the African American woman-her expression of vulnerability when she admitted difficulty in joining the group. Although the copresident's remark was friendly, it did not address or even recognize the new mother's concerns. In fact, it reinforced the long period of "dues" one had to pay to be able "to understand what one was talking about."

Indeed, African American mothers reported feeling excluded from the home and school associations. Marcy Randolph, an African American parent, spoke about one of the elementary school's home and school associations.

I found in the elementary school I felt uncomfortable because I was maybe one of two minorities there. That's partly because it was during the day. And when they do it at 
night, it's usually when you are getting home from work. [Mrs. Randolph suggests,] Maybe Saturdays? I don't know if people would come on Saturdays. ... It seems the same people always do the same things and whenever someone wants to do something different, there's always a problem.

[I ask her how to get more representation from minority parents]. So many years minorities have tried to get into PTOs, but there is, you can't put your finger on it, a fear. I know a couple of years ago at Longview [Elementary School], they had an international assembly, children dressed in different costumes. It was wonderful. Koreans, all countries in their ethnic clothes. But I understand that the PTO didn't want to do it. The [nonPTO] parents loved it, the Koreans. . . . I remember there was so much of a controversy, and I don't understand it. (Parent, interview, June 3, 1996)

The underrepresentation of African American mothers in home and school associations also reflected racial differences in the role school played in mothers' lives. At Minsi Trail, for instance, there was some suggestion that the White upper-middle-class mothers turned to schools for the kind of social supports that other mothers already had established in their extended families, churches, and neighborhoods.

In the following passage, an African American administrator, and mother of students in another local school district, compared her own parent involvement with the involvement of White parents at one of Minsi Trail's wealthier elementary schools. She suggested that high levels of upper-middle-class White parent involvement were related to the absence of family and other social supports resulting from the parents' residential mobility.

I never attended a PTO meeting, I still don't attend them. I just prefer, as an educator, to assist in ways that the school has asked, and I'm not necessarily-the parents have good intentions - but I am not interested in doing what the PTO wants to do. Sometimes they are off track and I don't see the need in having family outings on the weekends with people in the school. That's not my thing. But if the school needs something, I'll try to do it.

[I ask why not]. Why not? Oh, primarily because [she's laughing] we have a life and community and family outside the school and I don't depend on the school for community or for friendship for myself. You often hear from PTOs, "We have to build a community." I have a different community. A lot of people are here without relatives and a lot don't go to church, so the school is the place where they are connected with other adults. I have enough outside of school. (Administrator, interview, May 13, 1996)

This administrator and mother located African American parents' lower levels of school involvement in their commitment to the social environment outside of school. In contrast, she located the involvement of upper-middle- 
class White parents in their lack of other social connections. She suggested that the White upper-middle-class parents networked through schools because their residential mobility (related to their class mobility) left them without family and community social supports. Thus, what appears to be a social deficiency of the upper-middle-class parents in the eyes of this African American woman was transformed into a school advantage for their children, as these parents turned to schools for social support and recognition (as expressed by the success of their children).

Taking a broader view, we need to understand the role of schools in people's lives in terms of their lifelong access to schools. The sites of social networks (school, church, family, neighborhood) are determined in part by access. Upper-middle-class White mothers may have turned to schools partly for social support. And, working-class and racial minority mothers often may have had other ready-made social networks through extended families, church, and lifelong residence or segregation in neighborhoods. However, one could imagine African American or working-class mothers networking through schools, if relatives, fellow church members, and neighborhood friends were also active in the local schools. The schools, like churches, presumably are local institutions that have been present throughout these mothers' lifetimes. Instead, White mothers had greater access to schools. Thus, school involvement developed into a central part of many of these mothers' lives.

Part of the unwelcome feeling African Americans experienced at the home and school association meetings may have been a response to their questioning of the existing policies and procedures. The following exchange with an involved parent at the high school illustrates the ambivalence of some White upper-middle-class parents. This passage is from the high school staff appreciation luncheon hosted by the high school home and school association. Suzanne Prine, an involved, upper-middle-class White mother, spoke about the lack of parent volunteers in the association.

She is talking about seeing the same people over and over, helping at school, etc., and how there are getting to be fewer parents helping. [I mention I'd like to see more diversity in parents at school.] She points out Rayne Johnson, the African American mother and social services worker in the city who comes to meetings, and says that all Mrs. Johnson does is complain at meetings. "There are bad things happening everywhere, but this place is pretty good," Mrs. Prine says. "Why does she have her kids here, if she doesn't like it?" (Field notes, November 10, 1995)

Unpacking this interchange provides an example of the kind of racism we observed in the expressed attitudes of several of the most active White 
mothers. First, Mrs. Prine responds to a general expression of hope for more diversity by identifying one African American woman who always "complains." Her example thus goes from a mention of the class (diverse parents) to the individual (an African American parent) whom she implies represents the problem with the class. She then wonders why the individual lives "here, if she doesn't like it," implying that criticism equals dislike. Finally, the broader inference is left open that Mrs. Prine "belongs," whereas Mrs. Johnson is a visitor-a visitor who can "go back to where she came from," if she finds all not to her liking or, indeed, if she finds anything to criticize.

When different people join an activity, they bring not only different perspectives and voices but also different sets of problems. An elementary school administrator recognized the issues that could arise if more African American parents became involved in the school, especially if they became involved as a group. The administrator noted the scarcity of African American families in attendance at public school functions but was hesitant to attempt to organize these parents. The following illustrative passage is from "science night" at one of the elementary schools."

[I speak with the principal, who is with his wife and sister.] Almost immediately he says that it is too bad that they don't get more minorities [at these events], that it is noticeable to him, at least, that they aren't here. [An estimated 200 people, including 10 African Americans - almost all of whom are the family of one school administrator.]

I say that I've noticed the same at almost every event I have attended at night. I say, "Maybe you need an African American parents organization."

He is shaking his head before I finish the thought. He says, "Yeah, that sets up possibilities for division that I don't want to happen." It is already there, he says, and he does not want to feed it. He points to an African American mother and says how he and the home and school association are trying to get her involved, "but you can see how she's separate." (Field notes, October 13, 1995)

The passive exclusion of working-class and minority parents from the home and school associations avoided expression of divisions, while simultaneously reinforcing the divisions. It avoided direct expression of ill feelings, even as it stoked resentments. Also, it may have made for smoother communication (at least among this circle), as mothers and educators from similar backgrounds worked together. However, the homogeneity of the home and school associations masked the real diversity in student and family populations. It excluded the voices of African American mothers and the issues and resources that they could bring to the schools. Furthermore, it reduced African American mothers' access to the schools and to educators. Access to school and educators granted involved mothers access to 
knowledge about school and disproportionate influence with administrators and teachers.

As we shall see, involved mothers tended to use their access to educators in efforts to gain advantage for their own children, often at the expense of other children, especially African American students. This is most clearly illustrated by involved mothers' advocacy for tracking. ${ }^{10}$ These mothers' attraction to tracking was often based on their desire to separate their children from others they deemed unsuitable and to gain the most resources possible for their own children.

\section{UPPER-MIDDLE-CLASS PARENTS' ADVOCACY FOR TRACKING}

Ability tracking is a crucial route through which higher status children gain advantage. Moreover, tracking creates an opportunity for involved upper-middle-class parents to influence their students' schooling directly (Lareau, 1989; Lareau \& Shumar, 1996; Oakes, 1988). Children raised in higher status families tend to develop linguistic and other cultural characteristics, or "cultural capital," that schools reward with beneficial school placements (Bourdieu, 1977). In addition, as discussed above, upper-middle-class parents often know more than other parents about the importance of track placements and exercise greater influence over children's track placementsknowledge and influence they gain in part through higher levels of school involvement (Baker \& Stevenson, 1986; Lareau, 1989; Useem, 1992). Thus, tracking provides a mechanism through which higher status parents can pass advantage across generations; parent involvement in tracking increases the effectiveness of the mechanism.

Recognizing the benefits ability tracking affords their children, many upper-middle-class parents use their cultural capital to resist efforts to detrack (Wells \& Serna, 1996). They threaten to flee schools. They use their social networks within schools to influence policy. They reach out to middle-class parents for additional support. And, when de-tracking appears inevitable, they negotiate alternative advantageous placements for their children. However, when upper-middle-class parents are closely involved in schools, do they resist tracking or do they share the more egalitarian views of educators?

In Minsi Trail, most of the heavily involved upper-middle-class mothers favored tracking. In fact, involved mothers frequently pressed administrators for more tracking. Much of the discussion about tracking involved parents trying to separate their less academically successful children from other low achievers. After all, most of the involved parents had children who were not 
excelling in all of their subjects or, sometimes, in any of their subjects. A second factor driving parents' advocacy for tracking was the desire to gain competitive advantage for their children. Parents sought to position their children for higher education through track placements and access to educational resources in secondary and, even, primary school. Wealthier parents with children in the special education program often approached the school with similar intentions. For instance, some upper-middle-class parents sought to separate their special education children from other special education children, especially African American children. Often, they demanded that the district pay for private school placements.

The following excerpt from a meeting of parents and administrators is representative of involved parents' general advocacy for tracking. At this meeting, the assistant superintendent reported on the results of the Strategic Planning Action Team meetings. ${ }^{11}$ Also in attendance were eight White mothers, the superintendent, and the middle school principal. At this point in the meeting, the assistant superintendent has raised the issue of grouping students.

The Assistant Superintendent says that during the Curriculum Strategic Action Team meetings there was much discussion about the grouping of kids, especially during the transition years of fifth and sixth grade, and eighth and ninth grade. In particular, there was a lot of discussion about the grouping of kids in math "that seems to drive the course offerings that kids can take after that time."

A mother asks why the middle school is not tracking in reading, while it is tracking in math. Her question seems to resonate with other mothers. Some nod or lean forward.

The Assistant Superintendent says she had thought that "your math group determines how you travel in the pod, so the top math students are somewhat traveling in the same group. And, high math skills seems related with high verbal skills also."

The woman: "But you could have high math and not high reading or vice versa and how do you account for that?"

The Superintendent: "A lot of the research says that the kids seem to learn better when they are in flexible grouping — together by ability, alone [etc.]. The teachers have gotten good at doing that. The very same teachers look at math and say, 'Well, we really can't do that with [math].' The same teachers who teach language arts in mixed groups are more comfortable teaching math in ability groups. [They] haven't been able to transfer the method to math."

The Middle School Principal adds that kids high in math and low in reading have been switched for reading. And sixth grade students identified as needing help have been pulled out for help. (Field notes, April 16, 1996)

The Minsi Trail administration felt considerable pressure from involved, influential parents concerning tracking. Most administrators favored heterogeneous grouping. And, as the above example illustrates, they tended to resist 
efforts to increase tracking. But they did not attempt to reduce tracking. A middle school administrator expressed the parental pressure in this way:

Someone told me some schools are heterogeneously placed [untracked] in some districts. I say, okay. But wait till I'm retired. Because they're going to tear the doors off this place. (Administrator, field notes, September 26, 1995).

Parent advocacy for tracking was driven partly by concern with their children's potential peers. One upper-middle-class White parent in the interview sample, whose son was not doing well in the high school, was asked if she would allow him to take vocational courses, in which working-class and African American students were overrepresented. She said

No way I'll let him take it, because I don't want him rubbing elbows with those kids. I'd love for him to be able to do that stuff, wiring in his own household, carpentry, but there's no way. (Parent, interview, January 26, 1996)

Educators were well aware of involved upper-middle-class parents' desire for separation of their children from lower status children. They also understood a second issue driving the parents' advocacy for tracking: anxieties about their children's access to selective colleges. The following passage illustrates Minsi Trail educators' view of parent advocacy for tracking. The field notes are taken from a Supervisors' Meeting held in the fall while the Strategic Planning Action Teams were generating their proposed changes for the district. ${ }^{12}$ The passage begins with the superintendent complaining about many teachers' punitive evaluation systems, even as he expresses his understanding of the need for the high school to sort children for enrollment into colleges.

The Superintendent: "Our evaluation is still punitive. The goal is learning not evaluation. And we can do the selecting that gets kids into selective universities [and still not be punitive]."

One of the supervisors, Mr. McCarty, says: "Parents want a system of exclusion that keeps them [their kids] from having to have contact with kids not like their own [our emphasis]."

The Assistant Superintendent: " JJerks and unmotivateds' are the actual words they use."

Mr. McCarty is chairing the Curriculum Action Team for the Strategic Action Planning process. Discussion turns to his concern over plans for added tracking in the high school proposed by parents and teachers on his action team. But he is hesitant to use his full influence as a supervisor and as chair of the committee to eliminate the proposals. Teachers on the committee are advocating an additional track beneath the 
College Prep track, because they feel many students in the College Prep track lack the required skills. Parents on the committee want to add a track above College Prep, but beneath the Honors track. They want a track which allows them to re-place their children above the children in the College Prep track, which they feel is a General track (and therefore includes the "jerks and unmotivateds"). But they fear their children will struggle in an Honors track.

The discussion turns to a focus on teachers who do not handle heterogeneous classes well. But the Assistant Superintendent points out: "That's not going to change. In the end, the parents get to choose [the tracks students take]." The Assistant Superintendent expresses her displeasure over plans for additional tracking, especially tracks that do not prepare students for college: "We had this and didn't have the enrollment." She envisions the school watering down courses, creating additional ability tracks, and then the students reaching college, where there are no tracks, and many students failing.

Mr. McCarty says that he would support a "graduation" track.

The Assistant Superintendent responds: "We're talking about 8 percent [in this school district] who don't go to college. How do you convince the 92 percent to put their kids in non-College Prep levels?" (Field notes, November 29, 1995)

Involved parents' desires to separate their children from lower status children and their anxieties concerning college enrollment meshed in their advocacy for tracking. But administrators, looking at the bigger picture of overall demand for college enrollment, struggled to maintain placements that would position nearly all students in this well-to-do district for higher education and provide them the skills they would need to succeed in college.

Similar dynamics were in play within the special education program and between special education and regular education. Wealthier White parents with special education children consistently strove to separate their children from African American or working-class children. Similarly, these parents sought the most resources that they could get for their own children.

When special education administrators dealt with any parent or student, they had to bear in mind the precedents that they were setting. For example, if the district paid for private school for one student, knowledgeable parents could try to squeeze their own private schooling out of the district. Administrators had to balance the needs of particular students with the expected responses of the students' parents and other special education parents as well. In the following passage, a special education administrator has just taken a phone call from a mother concerning her daughter's placement in a program at a Catholic school.

Off the phone, the administrator talks about Rhonda, a girl at Bishop McCarthy. "We had a meeting last week. We have to provide some services for her at Bishop McCarthy if there is demonstrated a need that substantially harms her schooling and she's 
having a really tough time, socially. The mother wants her back in public school, but if she's not doing well in Bishop McCarthy with 600 or 700 kids, I don't know what's going to happen at Minsi Trail."

In response, the administrator is looking at Forward, which is the state approved private placement. If that fails to work out, then she has to pick the second place. However, she does not want kids going to private schools because then other parents would start demanding it. "Last week, a parent from Four Winds [a private program] tried to get us to pay. We won that one [in a Due Process hearing] because we offered a similar program here, just not a private school one." Many private schools press their parents to sue the school district for money. (Field notes, November 13, 1995)

In a conversation after the phone call, the special education administrator expressed frustration over wealthier parents' success in gaining concessions from the district, compared with other parents, who did not want to go near schools or did not know how to work the system. Wealthier parents were more likely to be comfortable and knowledgeable about approaching schools and they had more economic and legal resources with which to fight the school district.

The administrator said: "They'll want $\$ 3,000$ [in the form of resources or a placement], and it'll cost $\$ 8,000$ to fight it." Sometimes she will be approached by parents, both of whom are lawyers. This situation is no longer frightening to her, but it demonstrates the resources that some parents can bring to bear on the district. "But it's frustrating. The last lawsuit took four or five staff a half day each in testimony-that's a cost not only of salary, but time away from kids. And I'll think about the $\$ 3,000$ and how I could use it on kids who really need it." She says that it is really only at private school placements that the district draws the line and will fight parents no matter the cost. (Field notes, November 13, 1995)

The following quote is the special education administrator's summary of a 2-hour IEP (Individualized Educational Program) meeting at a high school in a neighboring district. ${ }^{13}$

That's an example of a couple of parents who know their rights pretty well. They've thrown their temper tantrums in the past to get what they want. I wouldn't say they're upper class, but they're middle-class [and white]. And they want all the "t"s crossed. A two hour meeting. A very expensive meeting.

$\$ 10,000$ placement out of district

$\$ 4,000$ itinerant services

OVR and MBF, which we don't pay for [these are programs the student may attend after graduation]. But the district will pay for the assessment, $\$ 650$, because they'll [the parents] get it done before he graduates. All unfunded mandates. Plus the salaries of everyone involved-two teachers, a counselor, a director of special education, 
another special education administrator, all required to be at the meeting. And all for a mildly retarded kid who will always be supported work [for example, in a workshop]. When we could spend the money on someone who has socioeconomic needs and could go onto college with some help. (Field notes, November 13, 1996)

Some parents attempted to separate their children from the other special education children, particularly African American children. In the following excerpt, a special education administrator spoke about interactions with parents concerning the placements of their children.

The administrator: "Parents want homogeneous grouping. I've had parents come in and say they have a problem with learning support, because African Americans are in the class. 'What are the odds of getting our kid into private school?' they'll ask. I say, 'Well, if you pay for it.' It's usually more subtle. Like they'll say, 'You know, you know ... the other kids just aren't the right kind of kids. . . ' I am blunt with them. I don't give an inch." She says that with the gifted program, when she first got to the district and started trying to put African American and other minorities (not Asian American, who are over-represented) in the gifted program [through alternative testing for some kids], "people put up a stink. They didn't think it was fair these other kids got alternative testing. I said, 'Your kids are white and wealthy. They are part of the dominant culture. You can't be biased against in a test, when you're part of the dominant culture."' (Field notes, November 13, 1996)

In summary, the same dynamics of exclusion and competition for resources that existed in regular education tracking manifested themselves within the special education program. Parents with the school knowledge and resources pressured administrators for special services. School district administrators, making business decisions, were often forced to comply, even though they felt that they were misspending money and contributing to existing inequities. Just as an impetus for tracking in the regular education program was parents' desires to keep their children away from the "jerks and unmotivateds," an impetus for special education parents' requests was sometimes a similar desire to separate their children from other special education children, especially African American children.

\section{CONCLUSION: PARENT INVOLVEMENT AND ACCESS TO EDUCATIONAL RESOURCES}

Parent school involvement, as envisioned by many policy makers and educators, has the potential to make significant contributions to public schooling in the United States. Expanded involvement of parents on decision-making bodies and as volunteers in schools can improve schools' services to children 
and families by making schools more accountable to parents. Furthermore, the presence of parents in schools and the responsiveness of schools to parents can strengthen ties between schools and families from socioeconomic, racial, and ethnic groups traditionally underserved by schools. Moreover, closer ties between parents and schools can help educators take advantage of parents' resources and their unique stores of knowledge concerning their children to better educate children.

However, our findings should caution policy makers and educators. First, in Minsi Trail, there were social class and racial differences in levels of parent involvement in home and school associations and at decision-making and informational sessions. Parent school involvement was dominated by a relatively few upper-middle-class White mothers. Second, in addition to structural impediments to working-class mothers' involvement (e.g., the scheduling flexibility required for extensive school involvement), we found that the involved upper-middle-class White mothers often acted, perhaps unintentionally, in ways that tended to exclude other mothers, especially African American mothers. Finally, having gained access to educators and decisionmaking bodies, many of these parents used their influence to advocate for tracking schemes intended to benefit their children, often explicitly at the expense of other parents' children. Involved parents sought differentiated placements in order to separate their own children from other children of lesser status and to position their children for greater access to higher education.

Can schools gain the intended benefits of parent involvement without the downside of involved parents excluding other parents and using their influence to promote their own narrow self-interests? We open our suggestions with an acknowledgment of the difficulties the problem poses. First, parents have every reason to involve themselves in and question their children's schooling. Furthermore, one would expect involved parents to seek the best possible educational experiences for their children. Second, upper-middleclass parents can place tremendous pressures on administrators. A Minsi Trail administrator expressed this sentiment perfectly when he imagined parents' response to heterogeneous grouping in the middle school: "They're going to tear the doors off this place."

A first step administrators can take is to recognize the role of involved parents in passively and actively excluding other parents from school involvement. Furthermore, they can recognize the problem for children's access to equal educational opportunities that limited parent involvement poses. Sensitized to these potential pitfalls, administrators can look for opportunities to include other parents and to better manage involved parents.

The findings suggest that administrators who want to expand the diversity of involved parents will need to perform active outreach. Most administrators 
recognize that broadening parent school involvement is complicated by issues of race, social class, and parents' lifelong experiences with schools. They might look more closely, however, at how the practices of involved parents can exclude others. Furthermore, they could encourage involved parents to do the same.

Administrators and parents may decide that parents who are new to school involvement or represent racial, ethnic, social class, or gender groups that are underrepresented at schools may need to begin school involvement with their own homogeneous groups. This would reduce the isolation of new and different parents. Moreover, it would help minority voices be heard. Initially, this may raise the divisions that many administrators want to keep hidden. However, skillfully managed, administrators may use the expanded parent involvement to broaden their own support in the school community.

Administrators cannot change the work schedules of working-class mothers to make them more available for school involvement during the day. Similarly, Minsi Trail administrators' efforts to move parent involvement activities out of the workday have produced few results. The heavy and inflexible work schedules of many parents make school involvement difficult, especially among working-class parents. Furthermore, many African American parents choose to spend free time in non-school-related activities. However, many African American and working-class families contain unseen parenting resources in extended families and neighborhood friends. If they network through family, neighborhood, and church, then administrators can seek out those networks and invite them into the school community. Administrators can take a similar approach toward expanding the involvement of other minority groups.

The involvement of extended kin and friendship networks requires rethinking notions of home and school associations. Rather than parentteacher organizations, these associations might stress the support that other community members can and do provide schools and children. Furthermore, they could recognize the very real stake the community at-large has in local education.

A second step administrators can consider to expand involvement concerns their responses to parent requests. When presented with demands from individual or small groups of parents, administrators can attempt to broaden them. When parents make requests on behalf of their own children, the administrator may recognize that others could gain from the same request. Presented with a parental request, administrators can also attempt to involve other parents influenced by the request. It may be that other families could benefit; it may be that they would be harmed by the request. In either case, by opening discussion, the administrator can ensure that the request, as is or 
modified through discussion, represents the best interests of the school and the school district. In fact, individual parent requests may present opportunities to involve more parents. Again, this will require administrators to make active outreach efforts. In addition, the involvement of many parents over a contentious issue can create just the kind of public relations problem that drains the energy and patience of administrators. However, managed appropriately, expanded parent involvement can broaden administrators' bases of community support.

Third, administrators need to manage parent involvement. This is difficult, because involved parents are influential and can make considerable trouble for administrators. They often have contacts on school boards and local taxpayers' groups. They share social networks with administrators. And they are not reluctant to use their power to promote what they view as their children's welfare.

Management, under these circumstances, requires administrators to become educators to the broader system. First, they must find effective ways to stress to all school constituents their responsibility to all children and to the larger community. Second, they need to take as one of their central missions the task of continuously teaching parents about the benefits of having schools in which all children succeed.

Dealing with parent involvement is not easy. Indeed, the community politics it involves and the time, energy, and skills necessary to manage parent relations may be one of the major reasons administrative positions are so difficult to fill and keep filled. Nonetheless, our data suggest that managing such parental politics has become one of the central jobs of administrators who care about developing and maintaining high-quality, equitable schools.

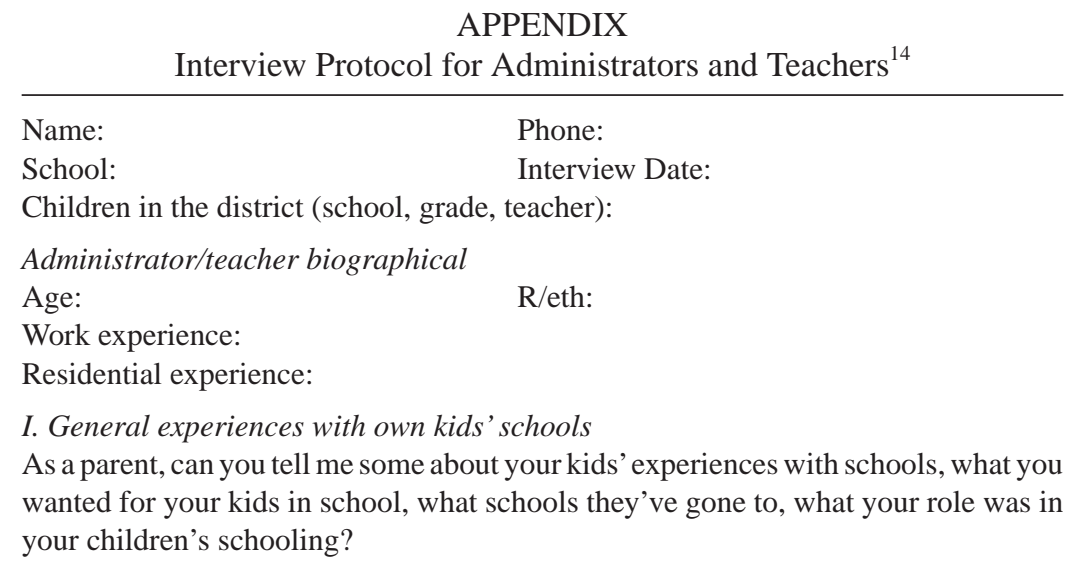


II. Your experiences with school

What kind of a kid were you in school? What did you want from school, what schools did you go to, what role did your parents take in your schooling?

III. What you do as an administrator/teacher

What things do you find you spend most of your time on as an administrator/teacher? What things do you think you spend too much time on?

What would you like to spend more time on?

If you had to liken your job to some other occupation, what would it be?

What would you want to be doing more?

What other occupation would you like your job to be like?

What do you read outside of school? Related to job?

IV. Parents' influence in schools

What do you think parents' role in schooling should be?

As it is, how much influence do you think parents, in general, have over schools?

How does the influence work, what form does it take?

How do you think you are involved in that influence?

V. Particular questions for the administrator/teacher, based on field observations, etc.

VI. Role of schools

What do you think schools should be for?

Compare that with what you think schools actually do.

What would the perfect school be like?

\section{NOTES}

1. We define parent school involvement as involvement at the school. We focus on this form of involvement because school involvement is especially suited to gaining influence in the school.

2. We define social class in terms of wealth, income, and profession. Upper-middle class refers to parents who either hold a professional job or can otherwise sustain (e.g., through owning a business, inheritance) a lifestyle commensurate with a professional salary. Professional class refers to professionals. Middle class refers to parents who work in trades, well-paying manufacturing jobs, or the lower rungs of management structures. Working class refers to everyone else.

3. Minsi Trail Schools and all the names of mothers and educators used in the article are pseudonyms.

4. The two townships had 1989 per capita incomes of $\$ 31,753$ and $\$ 28,788$; the workingclass borough had a 1989 per capita income of $\$ 15,778$ (Bureau of the Census, 1996).

5. Race issues may have included more than a conflation of race and social class at Minsi Trail, but we (two White males) did not gain evidence to support any broader conclusions (see Wells \& Serna, 1996, for an alternative explication of the racial intentions of elite White parents).

6. Home and school association or home and school were the terms parents and educators typically used to describe parent-teacher organizations. PTO was also used occasionally.

7. In the block-quoted excerpts from field notes and interviews, brackets enclose comments that we have added to clarify the speaker's statement. Following American Psychological 
Association (1994) style, the entire block quote should be read as a quotation from the interview, from the observation subject, or from the field notes. Quotations within the block quote indicate a second layer of quotation.

8. Principals and Presidents Meetings were meetings of the principals and home and school copresidents from each school and the superintendent and assistant superintendent. The meetings were held about three times a year.

9. Science night was arranged by a White mother on leave from her university science position. The gym, library, and several halls were filled with hands-on activities for children.

10. See McGrath and Kuriloff (1999) for documentation of parent involvement in the actual placement of students in tracks and programs.

11. The state-mandated strategic planning involved administrators, teachers, parents, students, and other community members developing a policy agenda for the future of the school district.

12. The supervisors were part-time teachers and full-time heads of their subject departments. Most of the supervisors were cochairs, often with teachers or parents, of Strategic Planning Action Teams organized around specific school issues (e.g., communications, diversity, curriculum). Supervisors' Meetings were held monthly through the school year. hers.

13. The senior author was present at this meeting and his observations were consistent with

14. The interview protocol for parents was similar to that used for the educators.

\section{REFERENCES}

American Psychological Association. (1994). Publication manual of the American Psychological Association (4th ed.). Washington, DC: Author.

Baker, D. P., \& Stevenson, D. L. (1986). Mothers' strategies for children's school achievement: Managing the transition to high school. Sociology of Education, 59, 156-166.

Bourdieu, P. (1977). Cultural and social reproduction. In J. Karabel \& A. H. Halsey (Eds.), Power and ideology in education (pp. 487-511). New York: Oxford University Press.

Bureau of the Census. (1996). 1990 Census look up data STF3A [Online]. Available: http:// venus.census.gov/cdrom/lookup

Comer, J. (1984). Home-school relationships as they affect the academic success of children. Education and Urban Society, 16, 323-337.

Connell, R. W., Ashenden, D. J., Kessler, S., \& Dowsett, G. W. (1982). Making the difference: Schools, families and social division. Boston: Allen and Unwin.

Epstein, J. L. (1991). Paths to partnership: What we can learn from federal, state, and school initiatives. Phi Delta Kappan, 72, 345-349.

Fair access to public schools [Editorial]. (1996, May 18). New York Times, p. 14.

Fine, M. (1993). [Ap]parent involvement: Reflections on parents, power, and urban public schools. Teachers College Record, 94, 682-710.

Kohn, A. (1998). Only for my kid. Phi Delta Kappan, 79, 568-577.

Lareau, A. (1989). Home advantage: Social class and parental intervention in elementary education. Philadelphia: Falmer.

Lareau, A., \& Shumar, W. (1996). The problem of individualism in family-school policies. Sociology of Education, 69(Suppl.), 24-39.

Levin, H., \& Hopfenberg, W. S. (1987). Accelerated schools for at-risk students. Education Digest, 56, 47-50. 
McGrath, D. J. (1997). Parent involvement in schools, the intergenerational transfer of occupational and economic success, and the grouping of students: Lessons from suburbia. Unpublished doctoral dissertation. Philadelphia: University of Pennsylvania.

McGrath, D. J., \& Kuriloff, P. J. (1999). The perils of parent involvement: Tracking, curriculum, and resource distortions in a middle school mathematics program. Research in Middle Level Education Quarterly, 22(3), 59-83.

Metz, M. H. (Principal Investigator). (1988). Final report: Field study on teachers' engagement project on the effects of the school as a workplace on teachers' engagement-Phase one: National Center on Effective Secondary Schools. Research supported by the National Center on Effective Secondary Schools, OERI.

Minsi Trail School District. (1996). Student achievement assessment report, 1994-95. Includes additional background statistics not found in the bound volume. Minsi Trail: Author.

Moles, O. C. (1987). Who wants parent involvement: Interest, skills, and opportunities among parents and educators. Education and Urban Society, 19, 137-145.

Oakes, J. (1988). Tracking in mathematics and science education: A structural contribution to unequal schooling. In L. Weis (Ed.), Class, race, and gender in American education (pp. 570-608) New York: State University of New York Press.

Perry, W., \& Tannenbaum, M. D. (1992). Parents, power, and the public schools. In L. Kaplan (Ed.), Education and the family (pp. 100-115). Needham Heights, MA: Allyn \& Bacon.

Philadelphia School District. (1995). Children achieving: Action design. Philadelphia: Author.

Rich, D. (1988). Bridging the parent gap in education reform. Educational Horizons, 67, $90-92$.

Saravia-Shore, M., \& Martinez, H. (1992). An ethnographic study of home/school role conflicts of second generation Puerto Rican adolescents. In M. Saravia-Shore \& S. Arvizu (Eds.), Crosscultural literacy. Ethnographics of communication in multiethnic classrooms (pp. 227-251). New York: Garland.

Useem, E. L. (1992). Middle schools and math groups: Parents' involvement in children's placement. Sociology of Education, 65, 263-279.

Warner, I. (1991). Parents in touch: District leadership for parent involvement. Phi Delta Kappan, 72, 373-375.

Wells, A., \& Serna, I. (1996). The politics of culture: Understanding local political resistance to detracking in racially mixed schools. Harvard Educational Review, 66, 93-118. 